\title{
Effects of testosterone on the expression levels of AMH, VEGF and HIF-1 $\alpha$ in mouse granulosa cells
}

\author{
YING ZHANG $^{1-3^{*}}$, SHAN-FENG WANG ${ }^{1 *}$, JIN-DAN ZHENG ${ }^{1}$, CHUN-BO ZHAO $^{1,4}$, \\ YI-NAN ZHANG ${ }^{1}$, LI-LI LIU ${ }^{1}$ and JIAN-HUA HUANG ${ }^{5}$ \\ ${ }^{1}$ Department of Obstetrics and Gynecology, The First Affiliated Hospital of Jinzhou Medical University, \\ Jinzhou, Liaoning $121000 ;{ }^{2}$ International Peace Maternity and Child Health Hospital and \\ ${ }^{3}$ Institute of Embryo-Fetal Original Adult Disease, Shanghai Jiao Tong University, School of Medicine, Shanghai 200030; \\ ${ }^{4}$ Department of Obstetrics and Gynecology, The Second Affiliated Hospital (Jiande Branch), \\ Medical School of Zhejiang University, The First People's Hospital of Jiande, Hangzhou, Zhejiang 311600; \\ ${ }^{5}$ Department of Key Laboratory of Tissue Engineering, The First Affiliated Hospital of Jinzhou Medical University, \\ Jinzhou, Liaoning 121000, P.R. China
}

Received October 28, 2014; Accepted October 22, 2015

DOI: $10.3892 / e t m .2016 .3436$

\begin{abstract}
The present study aimed to investigate the effects of testosterone on mouse granulosa cell morphology, and the expression levels of anti-Müllerian hormone (AMH), vascular endothelial growth factor (VEGF) and hypoxia-inducible factor-1 $\alpha$ (HIF-1 $\alpha)$. Mouse granulosa cells were isolated and identified, and their morphology was examined using hematoxylin and eosin, F-actin, and follicle-stimulating hormone receptor staining. The mRNA expression levels of $\mathrm{AMH}, \mathrm{VEGF}$ and HIF-1 $\alpha$ were examined using reverse transcription-quantitative polymerase chain reaction, and their protein secretion levels were investigated using enzyme-linked immunosorbent assays. Testosterone treatment did not affect granulosa cell morphology; however, it significantly increased the mRNA expression levels of AMH and VEGF, and the protein secretion levels of AMH, VEGF and HIF-1 $\alpha$. These results suggested that testosterone was able to regulate the functions of granulosa cells by upregulating the expression levels of AMH, VEGF and HIF-1 $\alpha$.
\end{abstract}

\section{Introduction}

Androgens, including testosterone, androstenedione and dihydrotestosterone, have been reported to have roles in female

Correspondence to: Professor Li-Li Liu, Department of Obstetrics and Gynecology, The First Affiliated Hospital of Jinzhou Medical University, 5-2 People Street, Jinzhou, Liaoning 121000, P.R. China E-mail: clearsky315@sohu.com

*Contributed equally

Key words: testosterone, anti-Müllerian hormone, hypoxia-inducible factor-1 $\alpha$, vascular endothelial growth factor reproduction; however, their specific functions remain controversial (1). In a previous study, a low dose of testosterone was shown to promote the aggregation, growth and development of follicles, which may occur due to the ability of testosterone to increase the secretion of insulin-like growth factor 1 (2). Conversely, the apoptosis of preantral follicles and follicular granulosa cells may be induced by high levels of testosterone, which has been associated with upregulation of tumor necrosis factor (TNF)-related apoptosis-inducing ligand $(2,3)$.

Granulosa cells are involved in key physiological processes, including follicular growth, steroidogenesis and angiogenesis (4); however, little is known regarding the role of androgens in the growth and function of granulosa cells. In previous studies, the secretion of anti-Müllerian hormone (AMH) was increased in granulosa cells derived from preantral and small antral follicles $(4,5)$. In polycystic ovaries, increased serum expression levels of vascular endothelial growth factor (VEGF) have been associated with increased ovarian blood flow (6); however, the underlying mechanism, in particular the intra-ovarian autoregulatory mechanism, remains unknown.

Hypoxia-inducible factor- $1 \alpha(\mathrm{HIF}-1 \alpha)$ is a transcription factor that is sensitive to low oxygen tension, and is able to prevent fatal depletion of oxygen and subsequent cell death (7). Furthermore, there exists an inverse correlation between HIF-1 $\alpha$ expression levels and available oxygen, thus suggesting that HIF-1 $\alpha$ may be involved in determining oocyte developmental competence (8). Considering these findings (9-11), the present study aimed to investigate the effects of testosterone on the morphology of mouse granulosa cells, and the mRNA expression levels and secretion of AMH, VEGF and HIF-1 $\alpha$.

\section{Materials and methods}

Mice. Immature (5-week-old; $\mathrm{n}=20$ ) female Kunming mice were obtained from the Jinzhou Medical University (Jinzhou, China), and were housed in an air-conditioned environment under a 12-h light-dark cycle, with ad libitum access 
to a standard diet and water. The mice were injected with pregnant mare serum gonadotropin (10 IU; Ningbo Second Hormone Factory, Hangzhou, China), in order to stimulate folliculogenesis. After $48 \mathrm{~h}$, the mice were sacrificed using $45 \mathrm{mg} / \mathrm{kg}$ pentobarbital (2\%). All treatments and procedures were conducted in accordance with the Standards of Human Animal Care, as outlined in the National Institutes of Health (NIH) Guide for the Care and Use of Laboratory Animals (NIH, Bethesda, MA, USA). The mice handling protocols were approved by the Institutional Animal Care and Use Committee at Liaoning Medical University.

Cell culture and treatment. Following sacrifice, the ovaries of the mice were removed, dissected and the granulosa cells were collected, as described in a previous study (12). Purified granulosa cells were cultured in McCoy's 5A complete medium, supplemented with $1 \%$ follicle-stimulating hormone receptor (FSHR) antibiotics and $15 \%$ fetal bovine serum, at $37^{\circ} \mathrm{C}$ in an atmosphere containing $5 \% \mathrm{CO}_{2}$. In addition, the cells were cultured with testosterone $\left(10^{-7}\right.$ or $\left.10^{-6} \mathrm{M}\right)$, or in the absence of testosterone (control) for 24 or $48 \mathrm{~h}$. All reagents were purchased from GE Healthcare Life Sciences (Logan, UT, USA).

Granulosa cell identification. The purity of the granulosa cells was verified using hematoxylin and eosin (HE; Zhongshan Golden Bridge Biotechnology Co., Ltd., Beijing, China) and immunofluorescence staining. FSHR staining was used to identify and confirm the purity of the granulosa cells, as FSHR is specifically expressed on the surface of granulosa cells. The cells were counted using trypan blue staining (Sigma-Aldrich, St. Louis, MO, USA). The Olympus BX61 microscope (Olympus Corp., Tokyo, Japan) was used in these experiments.

Methyl thiazoyl tetrazolium (MTT) assay for granulosa cell viability. Isolated granulosa cells were resuspended in Dulbecco's modified Eagle's medium/F12 medium (Hyclone; GE Healthcare Life Sciences), and were adjusted to a concentration of $5.0 \times 10^{5}$ cells $/ \mathrm{ml}$ prior to seeding into 96 -well plates for culturing at $37^{\circ} \mathrm{C}$ in a $5 \% \mathrm{CO}_{2}$ incubator for 3-5 days. Four testosterone concentrations $\left(10^{-8}, 10^{-7}, 10^{-6}\right.$ and $\left.10^{-5} \mathrm{M}\right)$ were used to treat the experimental groups. The cells were cultured for $48 \mathrm{~h}$, after which $20 \mu \mathrm{l}$ MTT (5 mg/ml; Sigma-Aldrich) was added to each well and incubated for $4 \mathrm{~h}$ in darkness. Subsequently, $150 \mu 1$ dimethyl sulfoxide was added to each well, followed by agitation for $15 \mathrm{~min}$. The absorbance was measured at $570 \mathrm{~nm}$ using Multiskan MK3 microplate reader (Thermo Fisher Scientific, Inc., Waltham, MA, USA) and optical density (OD) values were calculated.

Total RNA isolation and reverse transcription-quantitative polymerase chain reaction ( $R T-q P C R)$. Granulosa cells were seeded into fibronectin-coated 6 -well plates at a density of $1 \times 10^{6}$ cells/well, and were treated with testosterone $\left(10^{-7}\right.$ and $10^{-6} \mathrm{M}$ ) for 24 or $48 \mathrm{~h}$. Total RNA was isolated using the PureLink RNA Mini kit (cat. no. 12183018A) and the KingFisher ${ }^{\circledR}$ robot, and was reverse transcribed into cDNA using the cDNA Reverse Transcription kit (all Thermo Fisher Scientific, Inc.). The specific primer sequences (designed by Invitrogen, Thermo Fisher Scientific Inc., Shanghai, China) were as follows: Mouse
AMH, forward 5'-CCCGCTATTTGGTGCTAACCG-3', reverse 5'-GGACTCATCCGCGTGAAACAG-3'; mouse VEGF, forward 5'-CCAAAGCCAGCACATAGG-3', reverse 5'-TCTCCGCTCTGAACAAGG-3'; mouse HIF-1 $\alpha$, forward 5'-TCCAAGCCCTCCAAGTATG-3', reverse 5'-GTGCCA CTGTATGCTGATG-3'; and mouse glyceraldehyde 3-phosphate dehydrogenase (GAPDH), forward 5'-ATCACTGCC ACCCAGAAG-3', reverse 5'-TCCACGACGGACACATTG-3'. qPCR was conducted using a reaction mixture of $2 \mu \mathrm{l}$ cDNA, $0.5 \mu \mathrm{l}$ forward and $0.5 \mu \mathrm{l}$ reverse primers (900 nmol/l), and 32.5 $\mu$ l SYBR Green PCR Master mix, within an ABI 7300 Real-Time PCR system (Applied Biosystems; Thermo Fisher Scientific, Inc.). The cycling conditions were as follows: $95^{\circ} \mathrm{C}$ for $10 \mathrm{~min}$, followed by 40 cycles at $95^{\circ} \mathrm{C}$ for $15 \mathrm{sec}$, and $60^{\circ} \mathrm{C}$ for $45 \mathrm{sec}$. The relative expression levels of the target genes were normalized to the GAPDH internal control. Data were analyzed using SDS 1.4 software (Applied Biosystems; Thermo Fisher Scientific, Inc.).

Enzyme-linked immunosorbent assay (ELISA). Granulosa cells $\left(10^{6}\right.$ cells/well) were cultured and treated with testosterone $\left(10^{-7}\right.$ and $\left.10^{-6} \mathrm{M}\right)$. The cell culture medium was collected after 24 and $48 \mathrm{~h}$ and stored at $-80^{\circ} \mathrm{C}$. The protein secretion levels were analyzed using the mouse AMH, VEGF and HIF- $1 \alpha$ ELISA kits, according to the manufacturer's protocol (DSL Chemicals Co., Ltd., Shanghai, China). The concentration of the protein was determined by measuring the absorbance at $450 \mathrm{~nm}$. Each experiment was conducted in triplicate.

Cytoskeleton F-actin staining. Granulosa cells were seeded into 6-well culture slides at a density of $\sim 3 \times 10^{4}$ cells/well in duplicate, and were treated with testosterone $\left(10^{-7}\right.$ and $\left.10^{-6} \mathrm{M}\right)$ for $48 \mathrm{~h}$. Subsequently, the cells were subjected to F-actin and FSHR staining, as demonstrated in a previous study (12). Briefly, the cells were fixed with $3.7 \%$ paraformaldehyde at $4{ }^{\circ} \mathrm{C}$ for $10 \mathrm{~min}$, after which they were treated with $0.5 \%$ Triton-X-100 for $15 \mathrm{~min}$ (for F-actin staining) or $3 \%$ hydrogen peroxide solution (for FSHR staining) for $5 \mathrm{~min}$. For F-actin staining, the cells were incubated with $2 \mathrm{U} / \mathrm{ml}$ rhodamine-phalloidin (cat. no. PHDR1; Cytoskeleton, Inc., Denver, CO, USA) for $1 \mathrm{~h}$ at room temperature in the dark, and were mounted using ProLong ${ }^{\circledR}$ gold antifade reagent (cat. no. p36930; Thermo Fisher Scientific, Inc.). The cell nuclei were stained using 4',6-diamidino-2-phenylindole (Invitrogen; Thermo Fisher Scientific, Inc.), following several washes. For FSHR staining, the slides were blocked with normal goat serum (cat. no. 36119ES03; Yeasen, Shanghai, China) for $20 \mathrm{~min}$, after which they were incubated with rabbit polyclonal anti-FSHR (1:100; cat. no. A3172; ABclonal Biotechnology, Co., Ltd., Hubei, China) overnight at $4^{\circ} \mathrm{C}$, followed by anti-rabbit fluorescein isothiocyanate-conjugated immunoglobulin $\mathrm{G}$ (1:200; cat. no. bs-0295G; Bioss Co., Beijing, China) for $60 \mathrm{~min}$. After washing with phosphate-buffered saline, the slides were mounted using mounting medium, and the slides were examined using an Olympus BX61 fluorescence microscope (Olympus Corporation, Tokyo, Japan).

Statistical analysis. Statistical analyses were conducted using SPSS 13.0 software (SPSS, Inc., Chicago, IL, USA). Data are presented as the mean \pm standard error of the mean. The mean 
A

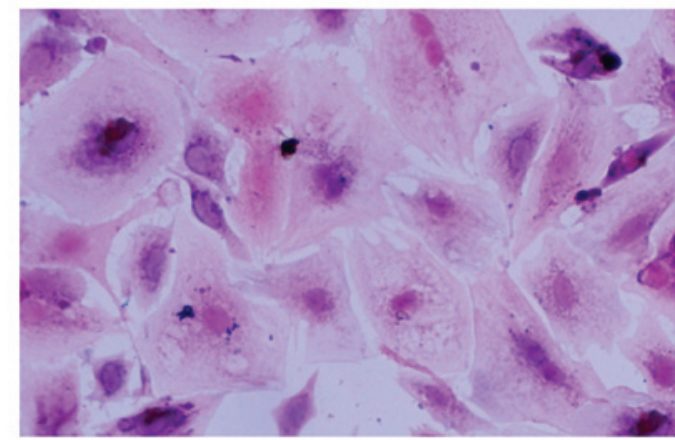

B

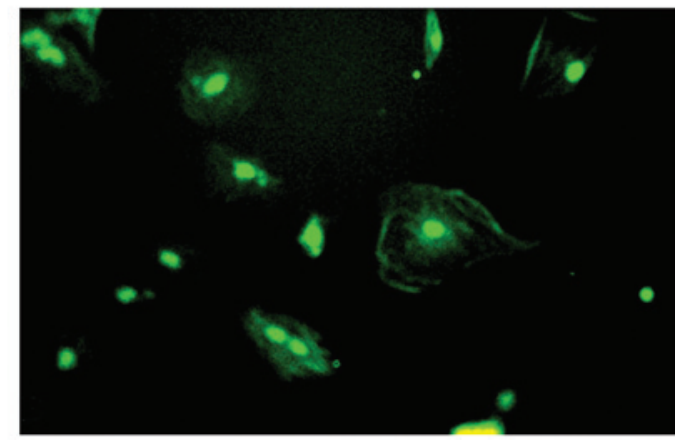

Figure 1. (A) Morphology of granulosa cells was analyzed by hematoxylin and eosin staining and (B) granulosa cells were identified using follicle-stimulating hormone receptor immunostaining (magnification, $\mathrm{x} 40$ ).

values were compared using one-way analysis of variance, followed by post-hoc tests: Tukey's honest significant difference test or Dunnett's test. $\mathrm{P}<0.05$ was considered to indicate a statistically significant difference.

\section{Results}

Granulosa cell identification. Granulosa cells were identified using trypan blue staining, HE staining and FSHR immunostaining. The cell viability of the granulosa cells was $80-90 \%$, as demonstrated by trypan blue staining. The purity of the granulosa cells was high, as demonstrated by the fact that $>90 \%$ of the cells were FSHR-positive (Fig. 1).

Effects of testosterone on the cell viability of granulosa cells. As compared with the control group, the cells treated with $10^{-8}$, $10^{-7}, 10^{-6}$ and $10^{-5} \mathrm{M}$ testosterone exhibited markedly increased viability, and those treated with $10^{-6} \mathrm{M}$ testosterone showed the greatest increase in viability (Fig. 2).

Effects of testosterone on cell morphology. The effects of testosterone on the nuclear and cytoskeletal morphology of granulosa cells are presented in Fig. 3. Following $48 \mathrm{~h}$ of exposure to testosterone $\left(10^{-7}\right.$ or $\left.10^{-6} \mathrm{M}\right)$, the morphology of the granulosa cells remained unaltered, consisting of large oval-shaped nuclei and well-organized F-actin fibers.

Effects of testosterone on the mRNA expression levels and secretion of $A M H$. The mRNA expression levels of $\mathrm{AMH}$ in the granulosa cells are presented in Fig. 4. Following $48 \mathrm{~h}$ of treatment with $10^{-7}$ and $10^{-6} \mathrm{M}$ testosterone, the mRNA expression levels of AMH were significantly increased $(\mathrm{P}<0.05$ and $\mathrm{P}<0.01$, respectively; Fig. $4 \mathrm{~A})$ compared with

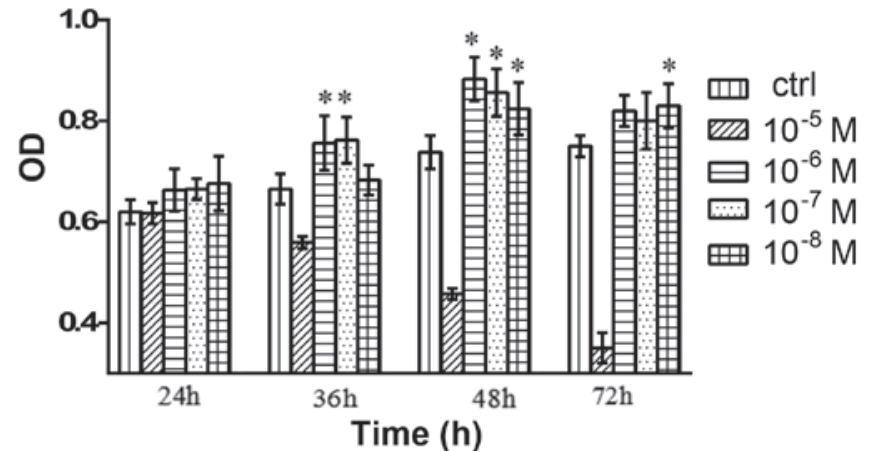

Figure 2. MTT analysis showing the effects of testosterone $\left(10^{-5}, 10^{-6}, 10^{-7}\right.$ and $10^{-8} \mathrm{M}$ ) on granulosa cell viability. "P<0.05 vs. control group. Ctrl, control; OD, optical density; MTT, methyl thiazoyl tetrazolium.

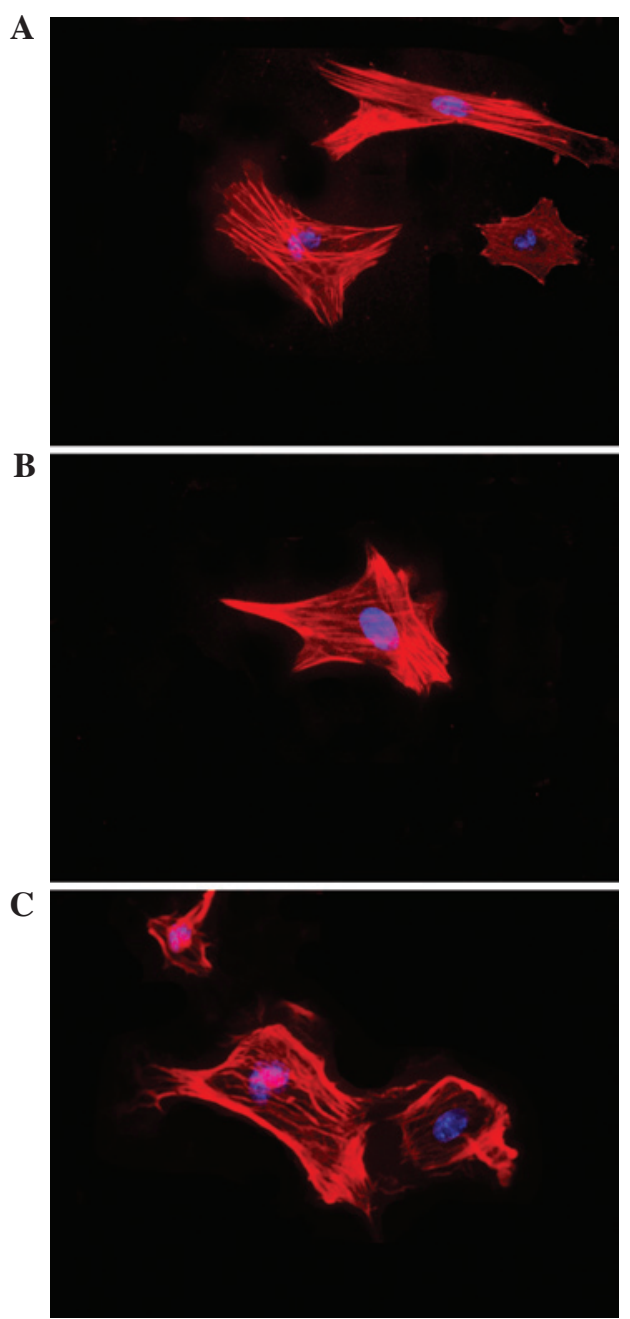

Figure 3. Effects of testosterone on granulosa cell morphology. Mouse granulosa cells were cultured (A) in the absence of testosterone, or with (B) $10^{-7} \mathrm{M}$ or (C) $10^{-6} \mathrm{M}$ testosterone for $48 \mathrm{~h}$. Cell morphology was evaluated using F-actin staining, and the nuclei were stained with 4',6-diamidino-2-phenylindole (magnification, $\mathrm{x} 40$ )

the control group. The concentration of secreted AMH in the granulosa cell culture medium was examined using ELISA. After $24 \mathrm{~h}$ of treatment with $10^{-7}$ and $10^{-6} \mathrm{M}$ testosterone, the concentration of secreted AMH was 207.64 $\pm 5.34(\mathrm{P}<0.01)$ and $183.64 \pm 1.86 \mathrm{ng} / 1(\mathrm{P}<0.01)$, respectively, which was significantly higher compared with the control group $(163.2 \pm 3.05 \mathrm{ng} / \mathrm{l}$; 

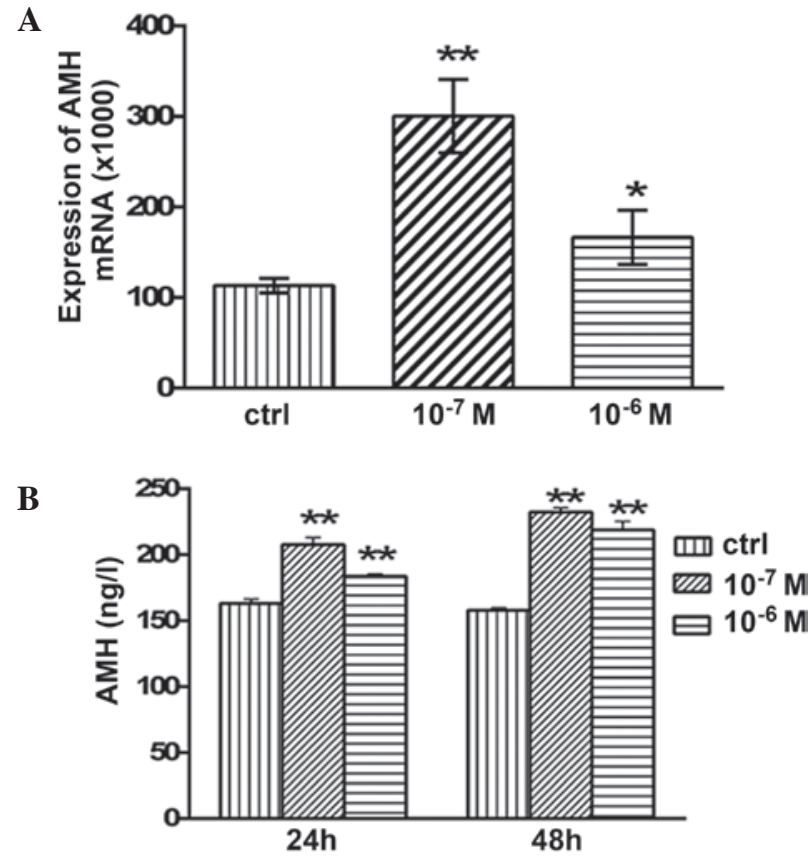

Figure 4. Effects of testosterone $\left(10^{-6}\right.$ and $\left.10^{-7} \mathrm{M}\right)$ on (A) mRNA expression levels of AMH at $48 \mathrm{~h}$ and (B) secretion of AMH at 24 and $48 \mathrm{~h}$. ${ }^{*} \mathrm{P}<0.05$ and ${ }^{* *} \mathrm{P}<0.001$ vs. the control group. Ctrl, control; $\mathrm{AMH}$, anti-Müllerian hormone.
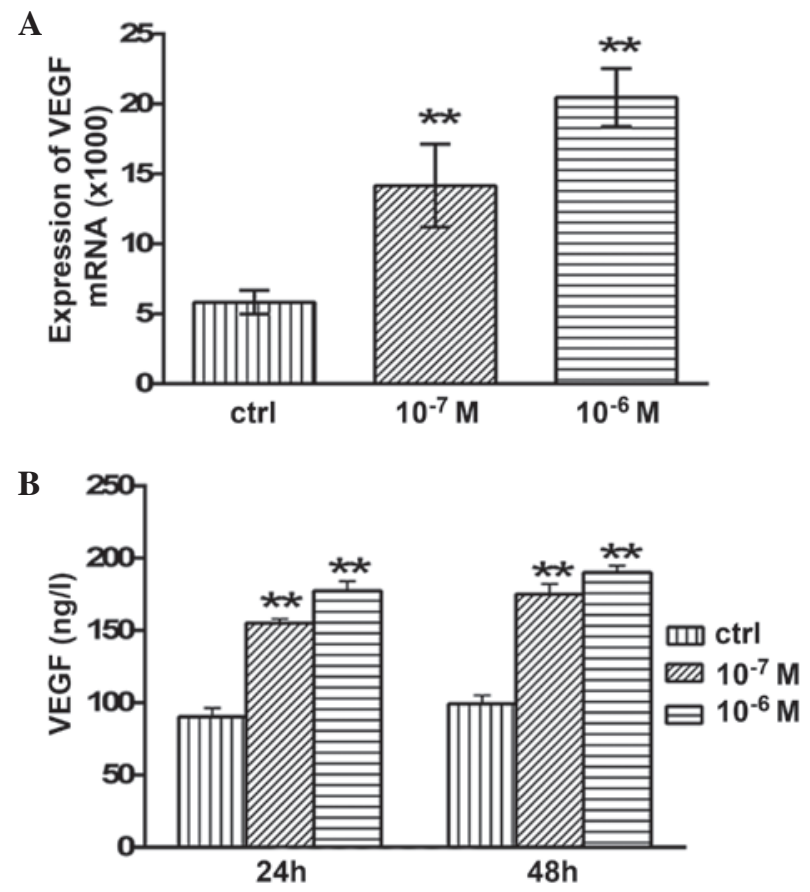

Figure 5. Effects of testosterone on the (A) mRNA expression levels of VEGF at $48 \mathrm{~h}$ and (B) secretion of VEGF at $24 \mathrm{~h}$ and $48 \mathrm{~h}$. ${ }^{* *} \mathrm{P}<0.001 \mathrm{vs}$. the control group. Ctrl, control; VEGF, vascular endothelial growth factor.

Fig. 4B). In addition, after $48 \mathrm{~h}$ of treatment with $10^{-7}$ and $10^{-6} \mathrm{M}$ testosterone, the concentration of secreted $\mathrm{AMH}$ was $232.4 \pm 3.05(\mathrm{P}<0.01)$ and $218.93 \pm 6.28 \mathrm{ng} / \mathrm{l}(\mathrm{P}<0.01)$, respectively, which was significantly higher compared with that of the control group (157.94 $\pm 1.94 \mathrm{ng} / \mathrm{l}$; Fig 4B).

Effects of testosterone on the mRNA expression levels and secretion of VEGF. After $48 \mathrm{~h}$ of treatment with $10^{-7}$ and
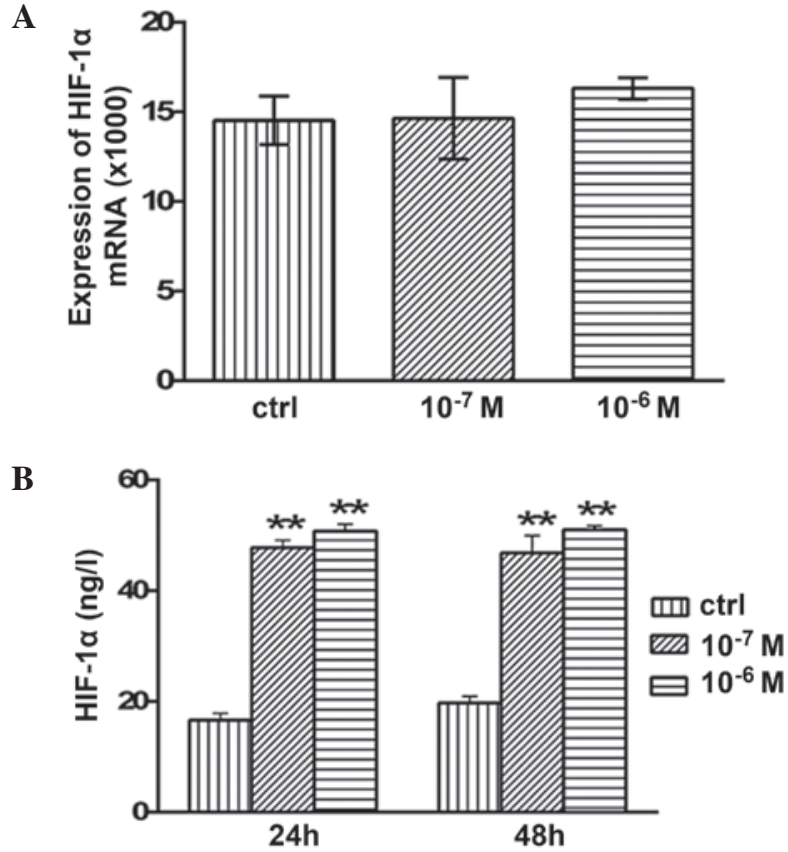

Figure 6. Effects of testosterone on the (A) mRNA expression levels of HIF-1 $\alpha$ at $48 \mathrm{~h}$ and (B) secretion of HIF-1 $\alpha$ at 24 and $48 \mathrm{~h} .{ }^{* *} \mathrm{P}<0.001$ vs. the control group. Ctrl, control; HIF-1 $\alpha$, hypoxia-inducible factor-1 $\alpha$.

$10^{-6} \mathrm{M}$ testosterone, the mRNA expression levels of VEGF in the granulosa cells were significantly increased $(\mathrm{P}<0.01)$ compared with the control group (Fig. 5A). In addition, the concentration of secreted VEGF protein was significantly increased following testosterone treatment. After $24 \mathrm{~h}$ of treatment with $10^{-7}$ and $10^{-6} \mathrm{M}$ testosterone, the concentration of secreted VEGF protein was 155.2 $\pm 2.91(\mathrm{P}<0.01)$ and $177.34 \pm 6.64 \mathrm{ng} / \mathrm{l}(\mathrm{P}<0.01)$, which was significantly increased compared with the control group $(90.4 \pm 6.01 \mathrm{ng} / \mathrm{l}$; Fig. 5B). After $48 \mathrm{~h}$ of treatment with $10^{-7}$ and $10^{-6} \mathrm{M}$ testosterone, the concentration of VEGF in the granulosa cell culture medium was $175.13 \pm 7.13(\mathrm{P}<0.01)$ and $190.18 \pm 4.79 \mathrm{ng} / \mathrm{l}(\mathrm{P}<0.01)$, respectively, which was significantly higher than that of the control group ( $99.26 \pm 5.89 \mathrm{ng} / \mathrm{l}$; Fig. 5B).

Effects of testosterone on the mRNA expression levels and secretion of $H I F-1 \alpha$. No significant alterations in the mRNA expression levels of HIF-1 $\alpha$ were detected following $48 \mathrm{~h}$ of treatment with $10^{-7}$ or $10^{-6} \mathrm{M}$ testosterone ( $>0.05$; Fig. $\left.6 \mathrm{~A}\right)$. However, the concentration of secreted HIF- $1 \alpha$ protein was $47.76 \pm 1.35(\mathrm{P}<0.01)$ and $50.77 \pm 1.24 \mathrm{ng} / \mathrm{l}(\mathrm{P}<0.01)$ after $24 \mathrm{~h}$ of treatment with $10^{-7}$ or $10^{-6} \mathrm{M}$ testosterone, respectively; this was significantly higher compared with the concentration in the control group (16.6 $\pm 1.29 \mathrm{ng} / \mathrm{l}$; Fig. 6B). In addition, after $48 \mathrm{~h}$ of treatment with $10^{-7}$ and $10^{-6} \mathrm{M}$ testosterone, HIF- $1 \alpha$ protein secretion was $46.83 \pm 3.12(\mathrm{P}<0.01)$ and $51.0 \pm 0.73 \mathrm{ng} / 1(\mathrm{P}<0.01)$, which was significantly increased compared with the control group (19.72 \pm 1.2 ng/l; Fig. 6B).

\section{Discussion}

The results of the present study demonstrated that testosterone was able to increase the mRNA expression levels and secretion of AMH, VEGF and HIF-1 $\alpha$ in cultured mouse granulosa 
cells. In addition, testosterone treatment did not exert discernible effects on granulosa cell morphology.

A previous study of primates demonstrated that testosterone may have a role in folliculogenesis $(13,14)$. Short-term administration of testosterone in rhesus monkeys increased the number of preantral follicles, and promoted the proliferation of theca and granulosa cells in ovarian follicles, whereas it decreased ovarian follicle apoptosis, as compared with a placebo (13). In addition, testosterone has been shown to regulate secretion from granulosa cells, which in turn may alter the follicular microenvironment (15).

$\mathrm{AMH}$, which is a member of the transforming growth factor- $\alpha$ family, is able to suppress the cyclical recruitment of primordial follicles. It is predominantly produced by preantral and early antral follicles, which are thought to serve as a proxy for various primordial follicles in the ovaries $(16,17)$. The present study demonstrated that testosterone was able to promote the upregulation and secretion of $\mathrm{AMH}$ in granulosa cells, thus suggesting that testosterone was able to affect follicular growth and development. A previous study reported that prenatal testosterone treatment was able to decrease the protein expression levels of AMH in the granulosa cells of preantral follicles, whereas it was able to increase its expression levels in those of antral follicles (18). The majority of the granulosa cells used in the present study were derived from cumulus granulosa cells and antral follicles. However, the specific mechanism underlying the regulation of AMH by testosterone requires further investigation.

VEGF is produced by follicular granulosa and ovarian theca cells in response to gonadotropin stimulation (19). VEGF was previously shown to initiate ovarian angiogenesis and to increase the permeability of blood vessels during the normal ovarian cycle (20). The present study demonstrated that testosterone was able to increase the mRNA and protein expression levels of VEGF in granulosa cells, which may serve to improve blood supply to the ovaries.

HIF- $1 \alpha$ is a heterodimeric transcription factor, which is produced by mammals and humans under anoxic conditions. HIF-1 $\alpha$ is the major regulatory factor in mammals for maintaining the oxygen balance, and oxygen is closely associated with the utilization of glucose in granulosa cells (7). However, the function of HIF-1 $\alpha$ in granulosa cells has rarely been studied. In the present study, testosterone treatment increased the secretion of the HIF-1 $\alpha$ protein. These results suggested that testosterone may improve the oxygen supply in granulosa cells and the energy metabolism in ovarian follicles, and thus contribute to follicular development. A previous study demonstrated that inhibition of VEGF in the primate ovary upregulates HIF-1 $\alpha$ expression levels in follicles (7). Consistent with this finding, the increased HIF-1 $\alpha$ secretion in the present study may be associated with upregulation of VEGF upon testosterone treatment.

Previous studies have suggested that testosterone was able to improve ovarian activity $(21,22)$; however, few studies have investigated the association between testosterone and AMH, VEGF and HIF-1 $\alpha$ in granulosa cells. The results of the present study suggested that testosterone was able to regulate the expression and secretion of $\mathrm{AMH}, \mathrm{VEGF}$ and HIF-1 $\alpha$; however, the underlying mechanisms require further investigation.

\section{Acknowledgements}

The present study was supported by grants from the Natural Science Foundation of Liaoning Province (no. 201102134) and the Jinzhou Municipal Science and Technology Program (no. 12A1E35). The authors would like to thank the Department of Key Laboratory of Tissue Engineering of the First Affiliated Hospital of Jinzhou Medical University for technical assistance.

\section{References}

1. Trivax B and Azziz R: Diagnosis of polycystic ovary syndrome. Clin Obstet Gynecol 50: 168-177, 2007.

2. Azziz R, Carmina E, Dewailly D, Diamanti-Kandarakis E, Escobar-Morreale HF, Futterweit W, Janssen OE, Legro RS, Norman RJ, Taylor AE and Witchel SF; Androgen Excess Society: Positions statement: Criteria for defining polycystic ovary syndrome as a predominantly hyperandrogenic syndrome: An Androgen Excess Society guideline. J Clin Endocrinol Metab 91: 4237-4245, 2006.

3. Barber TM, Wass JA, McCarthy MI and Franks S: Metabolic characteristics of women with polycystic ovaries and oligo-amenorrhoea but normal androgen levels: Implications for the management of polycystic ovary syndrome. Clin Endocrinol (Oxf) 66: 513-517, 2007.

4. Dokras A, Clifton S, Futterweit W and Wild R: Increased risk forabnormal depression scores in women with polycystic ovary syndrome: A systematic review and meta-analysis. Obstet Gynecol 117: 145-152, 2011.

5. Solomon CG: The epidemiology of polycystic ovary syndrome. Prevalence and associated disease risks. Endocrinol Metab Clin North Am 28: 247-263, 1999

6. Schneider JG, Tompkins C, Blumenthal RS and Mora S: The metabolic syndrome in women. Cardiol Rev 14: 286-291, 2006.

7. Duncan WC, van den Driesche S and Fraser HM: Inhibition of vascular endothelial growth factor in the primate ovary up-regulates hypoxia-inducible factor-1alpha in the follicle and corpus luteum. Endocrinology 149: 3313-3320, 2008.

8. Keith B, Johnson RS and Simon MC: HIF1 $\alpha$ and HIF2 $\alpha$ : Sibling rivalry in hypoxic tumour growth and progression. Nat Rev Cancer 12: 9-22, 2011.

9. van Disseldorp J, Faddy MJ, Themmen AP, de Jong FH, Peeters PH, van der Schouw YT and Broekmans FJ: Relationship of serum antimüllerian hormone concentration to age at menopause. J Clin Endocrinol Metab 93: 2129-2134, 2008.

10. Freeman EW, Gracia CR, Sammel MD, Lin H, Lim LC and Strauss JF III: Association of anti-mullerian hormone levels with obesity in late reproductive-age women. Fertil Steril 87: 101-106, 2007.

11. Ferrara N, Gerber HP and LeCouter J: The biology of VEGF and its receptors. Nat Med 9: 669-676, 2003.

12. Wang HX, Li TY and Kidder GM: WNT2 regulates DNA synthesis in mouse granulosa cells through beta-catenin. Biol Reprod 82: 865-875, 2010.

13. Vendola KA, Zhou J, Adesanya OO, Weil SJ and Bondy CA: Androgens stimulate early stages of follicular growth in the primate ovary. J Clin Invest 101: 2622-2629, 1998.

14. Weil SJ, Vendola K, Zhou J, Adesanya OO, Wang J, Okafor J and Bondy CA: Androgen receptor gene expression in the primate ovary: Cellular localization, regulation, and functional correlations. J Clin Endocrinol Metab 83: 2479-2485, 1998.

15. Duda M: The influence of FSH: LH and testosterone on steroidsecretion by two subpopulations of porcine granulosa cells. J Physiol Pharmacol 48: 89-96, 1997.

16. Seifer DB and Maclaughlin DT: Mullerian inhibiting Substance is an ovarian growth factor of emerging clinical significance. Fertil Steril 88: 539-546, 2007.

17. Tal R and Seifer DB: Potential mechanisms for racial and ethnic differences in antimüllerian hormone and ovarian reserve. Int J Endocrinol 2013: 818912, 2013.

18. Veiga-Lopez A, Ye W and Padmanabhan V: Developmental programming: Prenatal testosterone excess disrupts anti-Müllerian hormone expression in preantral and antral follicles. Fertil Steril 97: 748-756, 2012. 
19. Fraser HM and Duncan WC: Vascular morphogenesis in the primate ovary. Angiogenesis 8: 101-116, 2005.

20. Kisliouk T, Levy N, Hurwitz A and Meidan R: Presence and regulation of endocrine gland vascular endothelial growth factor/prokineticin-1 and its receptors in ovarian cells. J Clin Endocrinol Metab 88: 3700-3707, 2003.
21. Grzesiak M, Williams L and Luck MR: Testosterone influences water transport in porcine granulosa cells. Reprod Domest Anim 48: e52-e54, 2013.

22. Vanderhyden BC and Macdonald EA: Mouse oocytes regulate granulosa cell steroidogenesis throughout follicular development. Biol Reprod 59: 1296-1301, 1998. 